\title{
Patterns of Coding in Conversation Texts of the English Zone
}

\author{
Erwin Ashari \\ English Department \\ University of Riau Kepulauan \\ erwinashariharianja83@gmail.com
}

\begin{abstract}
The objectives of this study are; (1) to formulate patterns of coding used in conversation texts of the English Zone textbook, 2) to investigate how coding are structured in conversation texts of the English Zone textbook, and 3) to reason why the coding techniques are used in conversation texts of the English Zone textbook. The data were taken from conversation texts of students' English textbook: English Zone for senior high school students year grade XI (SMA). Descriptive qualitative method was used in this study. There were six conversation texts as the data source was taken from students' English textbook: English Zone. The findings of this study shown that there are two types of patterns of coding in conversation texts, namely congruent and metaphorical coding. Congruent coding patterns are built in complete mood and residue (at least using mood) and metaphorical coding patterns are built in elliptical mood pattern. Mood and residue pattern is caused by the system of the conversation is using Proposition system. It means the conversation texts involve the statement and question, in another word, the content of the conversation dominantly are about giving and demanding information. It was found that conversation texts convey the simple structure of conversation which means to attract the readers or students to understand easier by using complete mood and residue and elliptical mood pattern of conversation text is in less number. Thus, those conversation text in English Zone textbook written in simple structures in case of language usage to make the message or information easier to understand.
\end{abstract}

Keywords: English Zone Textbook; Congruent and Metaphor Coding;and Proposition System of Conversation Texts

\section{INTRODUCTION}

Wooffitt (2005:13) states that conversation examines language as social action. It means that everybody cannot avoid it in daily life. To share experience or knowledge we can conduct a conversation as the purpose of conversation is to exchange information, establish and maintain the relationship between people (Zhang, 2008:60). Talking about the conversation, it relates to the speech function and mood. Where the speech function is released or coded by the mood. Speech functions are; statement, question, command and offer while moods are declarative, imperative and interrogative. When students are reading a conversation in a textbook, sometimes they misinterpret the meaning or the theme of the 
conversation. It is caused of the coding of the mood in the text is not congruent or it is called metaphor (Saragih, 2006: 201). Based on the explanation in the background, the problems are formulated as the following, (1) What patterns of coding are used in conversation texts of the English Zone textbook? (2) How are the patterns of coding structured in conversation texts of the English Zone textbook? And (3) Why are the coding patterns used in conversation texts of the English Zone textbook?

\section{MATERIALS}

Discourse defines as verbal expression in speech or writing or verbal exchanged; conversation (Purwoko, 2008: 1). It means discourse analysis is a process to understanding the meaning of a language either spoken or written language. Discourse comprehension is about as easy to achieve as it is hard to grasp (Gurning, 2007: 1). Discourse is defined as a meaning that is realized in text (Saragih, 2007: 1). Meaning is represented by expression or text and expression represents meaning. It means, to express meaning, people use texts or expression. Every text has own meaning that are influenced by the context. There are three fields in the level of discourse; they are ideational, negotiation and identification. Negotiation itself refers to the conversation text. In conversation, it involves two participants, they are addresser and addressee. Saragih (2010) states conversation is structured in terms of move. In addition, systematically the realization of moves are related to Speech Functions and Moods. In this way, conversations are multi-dimensionally analyzed. it means that in negotiation there are three dimension that can be analyzed, they are move, speech function and mood. Move is defined as the function or role played by e speaker (addresser) in a conversation in its relation to the function or role played by the hearer (addressee) and the commodity being exchanged (Saragih, 2008: 14). It means that every clause that is uttered by either addresser or addressee is called move, in another word one utterance is one move. There are two kinds of the move in exchange structure or conversation, they are; exchange of information and exchange of goods and services.

The purposes of addressers producing language and their wants are called speech function. To exchange of addressers' experiences, speech function is used. The speech function is oriented to addressees' functional interpretation. In exchanging the structures, it requires some commodity that will be exchanged. in exchange structure, the language user only do two actions, they are demanding and giving (Saragih, 2006: 63). The two actions will be applied to the commodity, they are information and good and service. It means in 
doing conversation, Four specific activities or speech functions (Saragih, 2006:64) are derived as summarize in Table 1.

\section{Table 1}

Speech Functions (Saragih, 2006)

\begin{tabular}{ccc}
\hline \multirow{2}{*}{ ROLES } & \multicolumn{2}{c}{ COMMODITY } \\
\cline { 2 - 3 } & INFORMATION & GOOD AND SERVICES \\
\hline GIVING & STATEMENT & OFFER \\
DEMANDING & QUESTION & COMMAND \\
\hline
\end{tabular}

There are two aspects that are analyzed in conversation, they are move and speech function and its realization in mood (Saragih, 2010). In analyzing conversation, there are two possibility coding, they are unmarked or congruent coding and marked or metaphor coding. Congruent coding means that the structure moving of the conversation move is unmarked, it means the link is as normal structure. Metaphor is the replacement of one grammatical class by another (Halliday, 2006:32). It means, it is possible in conversation a speech function is not coded by its mood, when it occurs, it is called metaphor. The coding of exchange structure or conversation can be in various coding or not congruent is called metaphor coding (Saragih; 2006: 201). Metaphor coding in conversation refers to a term used in exchange structure involving moves, speech functions and its realization in moods. To improve students' English competence, students are given English textbook. Since textbook is a means of a formal manual instruction in a specific subject, especially one for use in schools or colleges. It is very fundamental in teaching and learning process, because it will help teachers and students in the educational activity, including timing use.

\section{METHODS}

A descriptive research design is applied in this study. Descriptive design simply describes what is going on what data shows; because it focuses on the natural characteristics of the data. In the other word, how a theory works in different phenomena. Descriptive is the collection of data to give explanation or description about the even or accuracy of the report (Moleong, 2002:6) in Hasibuan (2011: 41). Data of this research is clause found in conversation in student's English text book: English Zone. The five conversation texts will be broken up into single clauses. The whole single clauses in the 
conversation texts will be made as the data of this research. The data of the study is the conversation texts found in English Zone textbook for Grade XI Senior High School. It is written by Astuti (2010) and published in Jakarta by Penerbit Erlangga. The conversation texts that are chosen about "Self Introducing"“Giving Opinion”, "Talking About Animal Treatment", "Talking About Smoking", Talking About Adventure Story", and "Talking About Pamphlet".

The document is read and analyzed to find coding of the move, speech function and its realization in mood in conversation texts of the students' textbook. The procedures of collecting data by selecting the conversation texts textbook, retyping the conversation texts, breaking the clauses of conversation texts to be made as data and then printing out the data. Then data is analized by identifying conversation texts, the move, speech function and mood of the clauses of the conversation texts then $i$ dentifying types of coding, then finding or computing the percentages based on the types of coding, then describing coding and findings, then reasoning or elaborating why the dominant type is used in conversation texts of the students' English textbook. As Given (2008:10) states that to ensure the study's trustworthiness entails many of the strategies used in qualitative research may include; Credibility, Transferability, Dependability, and Conformability.

\section{RESULTS}

It is found that there were 102 clauses in all selected conversation texts of students' English textbook: English Zones. Where, 73 simple clauses and the complex clauses numbers are 29 complex clauses from the total clauses. Moreover, it can be described that there were two types of coding pattern in coding pattern in move found in conversation text of students' English textbook they are congruent and metaphor coding. To make it clear then it is tabulated into the following table.

Table 3

Description of Type Coding in Move in the Conversation Texts of Students' English Textbook: English Zones

\begin{tabular}{cccc}
\hline & Type & Number & Percentage \\
\hline a) & Congruent Coding & 56 & $\mathbf{5 4 . 9 0 \%}$ \\
b) Metaphorical Coding & 46 & $\mathbf{4 4 . 1 0 \%}$ \\
\hline Total & $\mathbf{1 0 2}$ & $\mathbf{1 0 0 \%}$ \\
\hline
\end{tabular}


So the total percentage of the congruent coding in move is $54.90 \%$ and $44.10 \%$ in metaphorical coding from the total numbers of the clause, 102 clauses. Based on the table 3, it is found that Congruent Coding more dominant than Metaphor Coding in coding pattern in move, even though the distance is very close. Moreover, it can be described that there are two types of coding pattern in coding pattern in realization of speech function and its mood found in reading text of students' English textbook they are congruent and metaphor coding. To make it clear then it was tabulated into the following tables.

\section{Table 4}

Description of Type Coding in Speech Function and its Mood in Conversation Texts of the Students' English Textbook: English Zone

\begin{tabular}{|c|c|c|}
\hline Type & Numbers of Clause & Percentage \\
\hline a) Congruent Coding & 84 & $82.35 \%$ \\
\hline b) Metaphorical Coding & 18 & $17.65 \%$ \\
\hline Total & 102 & $100 \%$ \\
\hline
\end{tabular}

Table 4 shows $82.35 \%$ of the whole conversation texts are in congruent coding. It can be said that only $17.65 \%$ of the whole conversation texts are in metaphor coding. It shows that Congruent Coding is more dominant than Metaphor Coding. In conversation or exchange structures, Offers and Commands are grouped together as proposals, while Statements and Questions as propositions. in Conversation Texts of Students' English Textbook: English Zone can be seen as follows.

Table 5

Proposal and Proposition in Conversation Texts of the Students' English Textbook: English Zone

\begin{tabular}{lll}
\hline Type & Numbers of Clause & Percentages \\
\hline a) Proposal & 10 & $9.8 \%$ \\
b) Proposition & 92 & $90.2 \%$ \\
\hline Total & $\mathbf{1 0 2}$ & $\mathbf{1 0 0} \%$ \\
\hline
\end{tabular}

Based on the table 5, it can be seen that the proposition mood system is more dominant, where proposition system means the conversation texts involve the statement 
and question, or it can be said that the conversation texts dominantly content asking and answering the questions. The moods system also has some pattern they are Mood and Residue and Elliptical Mood. Mood and Residue means the response uses mood (subject, finite and mood adjuncts) and residue (including predicator, complement and other adjuncts).

Table 6

Mood Pattern in Conversation Texts of the Students' English Textbook: English Zone

\begin{tabular}{lll}
\hline Mood Pattern & Numbers of Clause & Percentages \\
\hline a) Mood and Residue & 96 & $94.1 \%$ \\
b) Elliptical & 6 & $5.9 \%$ \\
\hline Total & $\mathbf{1 0 2}$ & $\mathbf{1 0 0} \%$ \\
\hline
\end{tabular}

Based on the table 6 , it can be seen that the mood and residue mood pattern is more dominant. In move and realization of speech function and its mood, congruent and metaphorical coding patterns used in conversation texts of students' English textbook: English zone. Congruent coding patterns are built in complete mood and residue (at least using mood) and metaphorical coding patterns are built in elliptical mood pattern. The usage of congruent coding pattern is caused that the conversation texts do not run in natural setting, it means the conversation texts do not based on the natural setting. Mood and residue pattern usage is caused by the system of the conversation is using Proposition system. It means the conversation texts involve the statement and question, or it can be said that the conversation texts dominantly content asking and answering the questions.

\section{DISCUSSION}

The dominance of the congruent coding in the level of move and speech function and its mood show that the conversation texts are presented to the students and teachers interaction in the classroom because the conversation between students and teacher dominantly involve asking and giving information. It is similar to what Sulaiman (2010) finds that the dominant speech functions used by the teacher and students in the classroom interaction are question and statement because both of them need information each others. So, in classroom interaction the congruent coding is better than metaphorical coding. Conversation text refers to ellipsis clause. The elliptical clauses lead the conversation to the 
metaphorical coding. it means that in daily life the patterns of coding in move and speech functions are dominated by the metaphorical coding.

In the finding of this research, it is also found the elliptical clause, and it does not change the perception of the readers in understanding the conversation texts. Ellipsis is found from the social context of language. The social context is the reconstruction of linguistic element previous and after. In the other, Ellipsis is another cohesive device. It happens when words are omitted and the phrase needs to be repeated. It can be said, even though, it is not written or uttered but the readers or listeners can feel the presence of the elliptical word itself. The use of elliptical mood is occurred by the understanding or comprehending the context. So, it is needed to comprehend it more and more because the elliptical mood will be faced in daily conversation, even elliptical mood clause more often found in daily life rather than it is not.

\section{CONCLUSION}

Conversation texts of students' English textbook: English zone consist of two coding patterns, they are congruent and metaphorical coding. The two coding occur in move and speech function and its moods refer to the mood system in conversation texts of students' English textbook: English zone. They are proposal and proposition. The usage of mood and residue pattern is caused by the system of the conversation is dominated by Proposition system.

It gives some implications for teaching to make teaching and learning process be better. It is caused by; first, the teachers of English and students familiarize with the coding pattern of move and the realization of speech function to its mood in clauses in the conversation texts and also the elliptical linguistic element of clauses which deal with social context in order to apply the better teaching and learning process. Second, coding patterns are very useful to comprehend in order to understand the context of the conversation texts. So, it is very important for teachers of English and students to comprehend coding pattern in move and speech function and its mood of conversation texts. Third, English teachers can apply the metaphorical coding in conversations in daily life that it is possible to face by the students in their lives, it makes the teaching and learning process runs well, but it is needed to understand that in daily life, the coding pattern is not always in congruent pattern but more in metaphorical coding either in move or speech function and its moods. 


\section{SUGGESTIONS}

In relation to the conclusions, It is suggested that the students should be aware of the coding patterns of conversation in order to comprehend the message that the writers mean and teachers should play their important roles in teaching learning process to introduce and to give attention to the Indonesian and foreign conversation cultures especially the coding pattern of conversation texts. The writer of English textbook, especially in the part of the conversation texts, should be consistent and intense to the theory of discourse and pragmatics and social context of language itself.

\section{REFERENCES}

Astuti, Eka Mulya. 2010. English Zone for senior high school students year XI, Jakarta : Erlangga.

Given, Lisa M. 2008. The SAGE Encyclopedia of University Qualitative Research Methods; volumes 1 \&2, Thousand Oaks, CA: Sage.

Gurning, Busmin, 2007. Jurnal Linguistik Terapan Pascasarjana UNIMED, vol 4: Discourse Comprehension; Pascasarjana; UNIMED.

Lepschy, Annette.2008. Handbook of Communication Competence; Communication training. Berlin :y Walter de Gruyter GmbH

Mazeland, H, 2009. Concise encyclopedia of pragmatics : Conversation Analysis. University of Southern Denmark, Denmark.

Purwoko, Herudjati. 2008. Discourse Analysis. Semarang: Macanan Jaya Cemerlang.

Sulaiman, Ruwaidah.2010. A Thesis; Speech Function in classroom Interaction (Unpublished), Medan; Pascasarjana Unimed

Saragih, Amrin. 2006. Bahasa Dalam Konteks Sosial. Medan: Pasca Sarjana UNIMED

2006. Introducing Systematic Functional Grammar (Unpublished Lecture notes). Medan: Pasca Sarjana UNIMED

2008. Discourse Analysis, (Unpublished Lecture notes). Pasca Sarjana UNIMED 
2011. Factual Writing, (Unpublished Lecture Notes). Pasca Sarjana UNIMED

Sinwongsuat, Kemtong. 2008. Journal of Language and Communication; Conversation Analysis; An Introduction From a Linguist's Perspective. Faculty of Liberal Arts Prince of Songkhla University. Hat Yai. Songkhla.

Wooffitt, R. 2005. Conversation Analysis \& Discourse Analysis. London : SAGE

Zhang, Zheng, 2008. International Education Studies Journal vol.1 : Discourse Analysis and Cultivation of Conversational Competence in English Class. Retrieved from: http://www.ccsenet.org/journal.html. Accessed on December 26th, 2011. 